\title{
The role of the p53 tumor suppressor in metabolism and diabetes
}

\section{Che-Pei Kung ${ }^{1}$ and Maureen E Murphy²}

'Department of Internal Medicine, Washington University School of Medicine, St Louis, Missouri, USA ${ }^{2}$ Molecular and Cellular Oncogenesis Program, The Wistar Institute, Philadelphia, Pennsylvania, USA
Correspondence should be addressed to C-P Kung or M E Murphy Email patkung@wustl.edu or mmurphy@wistar.org

\begin{abstract}
In the context of tumor suppression, p53 is an undisputedly critical protein. Functioning primarily as a transcription factor, p53 helps fend off the initiation and progression of tumors by inducing cell cycle arrest, senescence or programmed cell death (apoptosis) in cells at the earliest stages of precancerous development. Compelling evidence, however, suggests that p53 is involved in other aspects of human physiology, including metabolism. Indeed, recent studies suggest that p53 plays a significant role in the development of metabolic diseases, including diabetes, and further that p53's role in metabolism may also be consequential to tumor suppression. Here, we present a review of the literature on the role of p53 in metabolism, diabetes, pancreatic function, glucose homeostasis and insulin resistance. Additionally, we discuss the emerging role of genetic variation in the p53 pathway (single-nucleotide polymorphisms) on the impact of p53 in metabolic disease and diabetes. A better understanding of the relationship between p53, metabolism and diabetes may one day better inform the existing and prospective therapeutic strategies to combat this rapidly growing epidemic.
\end{abstract} Key Words - p53

- metabolism

diabetes

\section{Introduction}

Long regarded as the 'guardian of the genome', the functions of TP53 (hereafter p53) as a tumor suppressor have been extensively studied (Levine \& Oren 2009). More than half of human cancers possess mutations in either p53 or in genes whose protein products control p53 activity (MDM2 or CDKN2A). Following genotoxic or oncogenic stress, p53 exerts its tumor-suppressive activities mainly by acting as a transcription factor to transactivate gene expression. Under mild stress, activated p53 induces expression of growth-arrest genes, such as $C D K N 1 A / p 21$, to facilitate DNA damage repair. When encountering prolonged or catastrophic DNA damage, p53 triggers programmed cell death (apoptosis), primarily by transactivating genes that encode proapoptotic proteins, such as BBC3 (PUMA) and PMAIP1 (NOXA). Additionally, it has recently become appreciated that the significance of p53 reaches beyond the limits of cancer biology. Impact of p53 has been seen in a variety of physiological functions, including aging, innate and adaptive immunity, development, reproduction and neuronal degeneration (Danilova et al. 2008, Poyurovsky \& Prives 2010, Levine et al. 2011, Chang et al. 2012, Menendez et al. 2013). Additionally, the relationship between p53, metabolism and metabolic diseases has become a new focal point for p53 researchers (Sano et al. 2007, Vousden \& Ryan 2009, Berkers et al. 2013). This review will cover the role of p53 in metabolism, with focus on its role in diabetes.

Published by Bioscientifica Ltd. 


\section{Structure and function of the p53 tumor-suppressor protein}

p53 protein is made of 393 amino acids and uses a zinccoordinated DNA-binding domain to bind in a sequencespecific manner to DNA consensus elements that contain two copies of the sequence PPPCWWGYYY (where $\mathrm{P}=$ purine, $\mathrm{W}=\mathrm{A}$ or $\mathrm{T}, \mathrm{Y}=$ pyrimidine) separated by a spacer of $0-13$ nucleotides. Though it is intrinsically disordered, the amino terminus of p53 is the business end of the molecule; it is responsible for interaction with the negative regulator MDM2, which targets p53 for degradation. This domain becomes phosphorylated following stress, thereby reducing the affinity for MDM2, and increasing the affinity for transcriptional co-activators like p300/ CBP. The sequence-specific DNA-binding domain of p53 encompasses approximately two-third of this protein, and this is where the majority of mutations occur in tumors. These mutations are often missense mutations, and six commonly mutated residues account for up to $30 \%$ of the mutations in $\mathrm{p} 53$ found in human tumors; these are called 'hotspot' mutations (Fig. 1A). p53 binds to its consensus element as a dimer of dimers, and this is mediated by a C-terminal oligomerization domain. Finally, at the extreme $\mathrm{C}$ terminus is a highly basic disordered domain that binds to DNA in a nonspecific manner with high affinity; this domain is believed to 'scan' the DNA for double-strand breaks or gaps, whereupon p53 stalls and becomes phosphorylated by kinases that are activated by DNA damage, such as ataxia telangiectasia mutated (ATM) (for review see Vousden \& Prives 2009).

There are multiple stresses that stabilize p53 and activate it as a transcription factor: these include DNA damage, hypoxia, nutrient deprivation and DNA replication stress (Fig. 1B). Following these stresses p53 becomes stabilized and activated as a transcription factor, leading to the sequence-specific transactivation of genes such as the cyclin-dependent kinase inhibitor CDKN1A (p21/WAF1), which leads to growth arrest and senescence, or to proapoptotic genes like PUMA, PMAIP1 (NOXA) or $B A X$, which lead to cell death. In addition, p53 has a transcription-independent role in cell death, mediated by direct binding and oligomerization of BAX and BAK at the mitochondria (for review see Pietsch et al. 2008). In addition to target genes involved in growth arrest and cell death, p53 is also well-known to regulate target genes with roles in metabolism, such as the genes GLS2, SCO2, Ras-related associated with diabetes (RRAD) and TIGAR (for review see Berkers et al. 2013). Whereas the role of p53 in metabolism is only now becoming appreciated, recent data from genetically engineered mouse models of p53 function implicate this set of p53 target genes in tumor suppression (Brady et al. 2011, Li et al. 2012).

\section{Type 1 and type 2 diabetes}

Diabetes refers to a series of metabolic conditions characterized by high blood glucose, caused either by inadequate insulin production in the body or by impaired response to insulin. Type 1 diabetes accounts for approximately $10 \%$ of cases, and is caused by death and dysfunction of pancreatic beta islet cells, leading to an absence of insulin production. Type 2 diabetes, or adult-onset diabetes, is characterized by impaired or insufficient insulin response; this disease accounts for $90 \%$ diabetes cases, and it is estimated that there are close to over 340 million individuals in the world with type 2 diabetes. Risk factors for both forms of diabetes include family history, genetics and age. Risk factors for type 2 diabetes also include obesity and poor diet. Complications of diabetes include glaucoma, poor wound healing, hypertension, neuropathy, nephropathy (kidney disease) and higher risk of stroke (for review see Polonsky 2012).

Both type 1 and type 2 diabetes are severe diseases that are better managed with healthy diet and exercise. Whereas type I diabetes requires treatment with insulin, in some cases type II diabetes may not require insulin, and can be managed with non-insulin medications that increase the response to insulin or reduce blood glucose. These non-insulin medications include the agents metformin and thiazolidinediones, which increase the body's
A

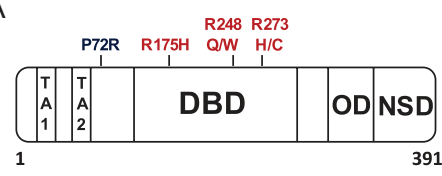

http://joe.endocrinology-journals.org DOI: $10.1530 / J O E-16-0324$

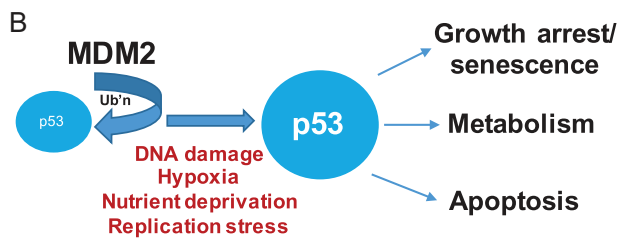

Figure 1

p53 structure and function. (A) Functional domains of $\mathrm{p} 53$. Outlined are the domains responsible for transactivation (TA1 and TA2), the codon 72 polymorphism (P72R), the DNA-binding domain (with some of the most common p53 'hotspot' mutations shown), the oligomerization domain (OD) and the nonspecific DNA-binding domain (NSD). (B) Overview of the p53 pathway. Ub'n, ubiquitin. 
sensitivity to insulin; sulfonylureas and meglitinides, which stimulate the pancreas to secrete more insulin; DPP-4 inhibitors and GLP-1 receptor agonists, which help lower blood glucose levels; and SGLT2 inhibitors, which prevent the kidneys from reabsorbing glucose into the blood (for review see Polonsky 2012).

\section{The tumor suppressor p53 influences diabetes}

The first evidence linking p53 to the development of type 2 diabetes came in 2009, when Minamino and colleagues demonstrated that diet-induced insulin resistance in Ay transgenic mice, which are susceptible to diabetes, is mediated by p53 (Minamino et al. 2009). This group showed that inhibition of p53 activity, either by siRNA knockdown in cells, or by TP53 gene knockout in mice, alleviated senescence and caused decreased inflammatory cytokine expression in the adipose tissue of mice, ultimately preventing them from developing insulin resistance. A year later, in a study focusing on the connection between nonhomologous end-joining (NHEJ) DNA repair mechanisms and p53, Tavana and colleagues discovered another unexpected connection between p53 and diabetes (Tavana et al. 2010). Specifically, knockout of Lig4 in mice resulted in NHEJ deficiency and embryonic lethality; not surprisingly, this embryonic lethality was rescued by p53 deficiency. The authors found that Lig4-/-; p53-/- mice developed B-cell lymphoma, but that introduction of a hypomorphic p53 mutant that fails to induce apoptosis but retains the ability to induce growth arrest and senescence (p53R172P) prevented the lymphomagenesis. However, the result was severe diabetes and early fatality in these mice; these were attributed to senescence of the pancreatic beta cells in these Lig4-/-; p53R172P mice. In sum, these studies implicated p53-mediated senescence of adipocytes and pancreatic beta cells, respectively, in the development of insulin resistance and diabetes.

\section{Diabetes phenotypes regulated by p53}

In general, there are three major causes of diabetes: (1) functional deficiencies in pancreatic insulin production, (2) aberration of glucose homeostasis and (3) development of insulin resistance. The available in vitro and in vivo evidence suggests that p53 is capable of having a significant impact on all three of these pathways.

\section{p53 regulates pancreatic function and survival}

One of the most common features of both type 1 and type 2 diabetes is dysfunction of pancreatic beta cells. Pancreatic beta cells are responsible for secreting insulin into the bloodstream; this lowers the circulating glucose level by stimulating glucose uptake (Cnop et al. 2005). Loss of pancreatic beta-cell function reduces insulin secretion and results in hyperglycemia and diabetes. Multiple signaling pathways converge upon p53 to regulate pancreatic beta-cell function (Fig. 2). Wrede and coworkers demonstrated that free fatty acids (FFA) increase apoptosis of pancreatic beta cells through reduced phosphorylation/activation of AKT (PKB) (Wrede et al. 2002); AKT is well known to normally protect cells from p53-mediated apoptosis by phosphorylating and activating the main negative regulator of p53, MDM2 (Mayo \& Donner 2001, Zhou et al. 2001). In a study that used FFA-treated beta cells to mimic visceral obesityinduced pancreatic dysfunction and apoptosis, p53 activation led to induction of the microRNA miR34a, which sensitized beta cells to apoptosis and inhibited the insulin exocytosis pathway, resulting in impaired insulin secretion (Lovis et al. 2008). In a pancreatic betacell line and in insulin-producing islet cells, the proinflammatory cytokines IFN- $\gamma$ and TNF- $\alpha$ were shown to synergistically function to increase reactive oxygen species (ROS) production, p53 induction and apoptosis (Kim et al. 2005). Finally, ROS were also found to be involved in FFA-mediated apoptosis of beta cells, and both ROS generation and p53 activation were shown to be downstream effects of NAPDH oxidase 2 (NOX2) (Koshkin et al. 2003, Yuan et al. 2010). In sum, these researchers found that FFAs, inflammatory cytokines and ROS can all act upstream of p53, to induce p53-mediated apoptosis of pancreatic beta cells.

Several proteins that regulate p53 are also influential in the death and survival of pancreatic beta cells. These include ARF-BP1, N-terminal truncated isoforms of p53, the transcription factor TCF7L2, and the microRNA miR-200. ARF-BP1 (also known as MULE or HUWE1) is a E3 ubiquitin ligase of p53 that controls p53 function in the $\beta$-cells (Kon et al. 2012). Transgenic mice with $\beta$-cell-specific deletion of arf-bp1 developed dysfunctional $\beta$-cells and died of severe diabetes before turning 1-year old. Concomitant deletion of p53 in the pancreatic $\beta$-cells reversed the phenotype and extended the lifespan of these mice. Hinault and coworkers showed that ectopically overexpressing the delta40p53 isoform of p53 in mice led to hypoinsulinemia and glucose intolerance en route

Published by Bioscientifica Ltd. 


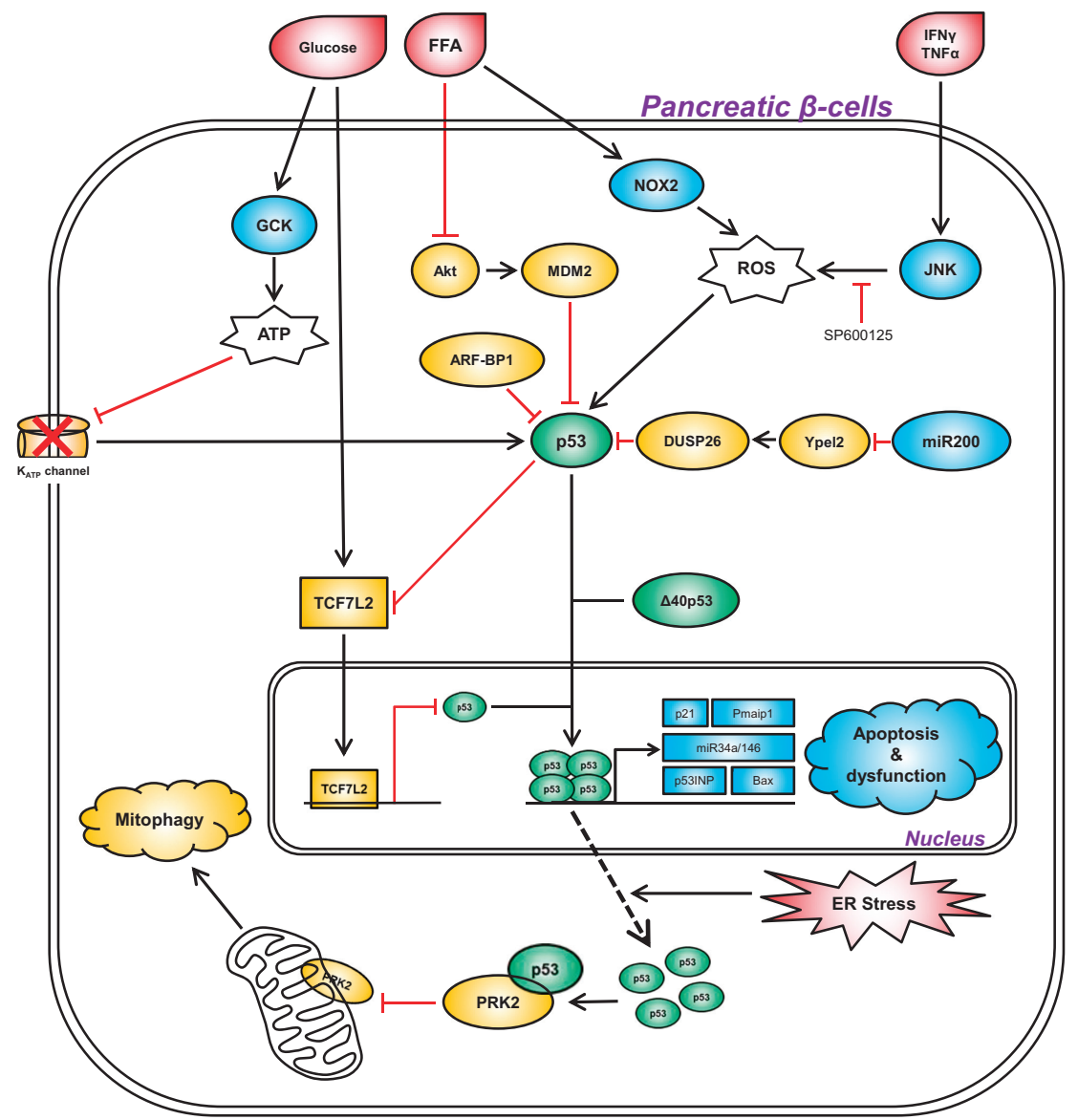

\section{Figure 2}

The regulation of pancreatic function by $\mathrm{p} 53$. In response to extrinsic (hyperglycemia, free fatty acid, inflammation) and intrinsic (ER stress) stresses (colored red), p53 is activated to trigger pancreatic dysfunction and impair insulin production through several mechanisms. The genes depicted in squares represent transcriptional targets of $p 53$. The genes colored in blue positively contribute to $p 53$ activation, while genes colored in orange inhibit p53mediated pancreatic dysfunction. Note that the $\mathrm{K}_{\text {ATP }}$ channel only activates $\mathrm{p} 53$ signaling in response to excessive ATP. FFA, free fatty acid; ROS, reactive oxygen species. to premature death (Hinault et al. 2011). delta40p53 is typically known to negatively regulate p53 transcriptional activity, but in some cell types it can positively regulate p53 function (Bourdon et al. 2005). In the case of pancreatic islet cells, delta40p53 led to increased expression of the cell cycle inhibitor p21/CDKN1A, a p53 target gene (Hinault et al. 2011). p53 function in the pancreas is also regulated by the transcription factor T-cell factor 7-like 2 (TCF7L2, also known as TCF-4). TCF7L2 maintains pancreatic beta-cell survival by physically binding to the p53 promoter and downregulating p53 expression (Zhou et al. 2012). Silencing of TCF7L2 leads to increased apoptosis by inducing expression of p53 and its apoptotic targets, including the proapoptotic target gene p53INP1. Notably, a single-nucleotide polymorphism (SNP) of TCF7L2 (rs7903146; C>T) is associated with impaired insulin secretion and increased risk of type 2 diabetes in Caucasians (Grant et al. 2006). Interestingly, TCF7L2 is also a p53-repressed target gene, suggesting there are feedback regulations between these two proteins (Rother et al. 2004). Finally, a recent study connected p53 with a microRNA, miR-200, along with pancreatic beta-cell apoptosis and lethal type 2 diabetes in vivo (Belgardt et al.
2015). Overexpression of miR-200 in beta cells activates p53 and creates a proapoptotic gene expression signature in diabetic mice. miR-200 inhibits the expression of its direct target YPEL2, which is responsible for maintaining the expression of DUSP26. DUSP26 (dual-specificity phosphatase 26) is a negative regulator of p53, and miR-200-mediated reduction of DUSP26 induces p53 activation and apoptosis (Shang et al. 2010). There are thus several proteins that regulate the p53 pathway, which can also regulate its ability to mediate pancreatic beta-cell death.

\section{p53 regulates dysfunctional beta cells during pre-diabetes By studying a rare monogenic disease,} congenital hyperinsulinism (CHI), p53 activity was found to be elevated during dysregulated beta-cell replication, a phenotype shared by CHI and pre-diabetes (TornovskyBabeay et al. 2014). In patients and mice with CHI, an activating mutation of glucokinase GCK and dysfunctional ATP-sensitive potassium channels $\left(\mathrm{K}_{\mathrm{ATP}}\right.$ channel) result in beta-cell membrane depolarization, hypersecretion of insulin and overactive glycolysis. Glucotoxicity triggers DNA damage and p53 activation, which ultimately results

Published by Bioscientifica Ltd 
in beta-cell death and late-onset diabetes (TornovskyBabeay et al. 2014). Two other processes regulated by p53, endoplasmic reticulum (ER) stress and dysfunctional autophagy, have also been implicated in beta-cell failure and hyperglycemia (Stavridi \& Halazonetis 2004, Las \& Shirihai 2010, Kung et al. 2011, Karunakaran et al. 2012). A recent study clarified this complex network by connecting diabetes-associated glucolipotoxicity with p53-mediated disruption of mitochondrial function (Hoshino et al. 2014). Specifically, in mouse models of both type 1 and type 2 diabetes, increased ER stress stimulates nuclear exportation and cytosolic accumulation of p53. This cytosolic p53 interacts with Parkin (PARK2) and inhibits Parkin-mediated mitophagy, resulting in mitochondrial dysfunction and insulin deficiency. Deletion or inhibition of p53 restores mitochondrial function and increases glucose tolerance (Hoshino et al. 2014).

\section{p53 regulates glucose homeostasis: glucose transport, glycolysis and gluconeogenesis}

Frank (or mature) diabetes is defined by an elevated level of circulating glucose. It often occurs concomitant with impaired glucose uptake in peripheral tissues such as muscle, adipose tissue, liver and the brain (Cherrington 1999). These phenotypes are in direct contrast to the enhanced cellular glucose uptake and glycolysis, better known as the 'Warburg effect', that is frequently observed in human tumors that contain mutations in p53 (Vander Heiden et al. 2009). Recent studies suggest that p53 exerts its tumor-suppressive activity, at least in part, through its ability to regulate glucose homeostasis (Madan et al. 2011). In the sections below we summarize the data indicating that p53 is an transport, glycolysis and gluconeogenesis, as well as insulin resistance.

p53 regulates glucose transporters Maintaining proper function of glucose transporters is critical in glucose homeostasis and suppression of diabetes (Shepherd \& Kahn 1999). p53 regulates the function of glucose transporters by affecting both their transcription and their translocation (Fig. 3A). For example, p53 activated by genotoxic stress can directly bind to the promoters of GLUT1 and GLUT4 and repress their transcription (Schwartzenberg-Bar-Yoseph et al. 2004). p53 also represses the expression of GLUT3, but this occurs through an indirect mechanism by inhibition of IkB kinase, or IKK (Kawauchi et al. 2008). Recent studies have also identified the role for p53 in the control of the localization of glucose transporters. Tumor-associated mutant forms of p53, such
A

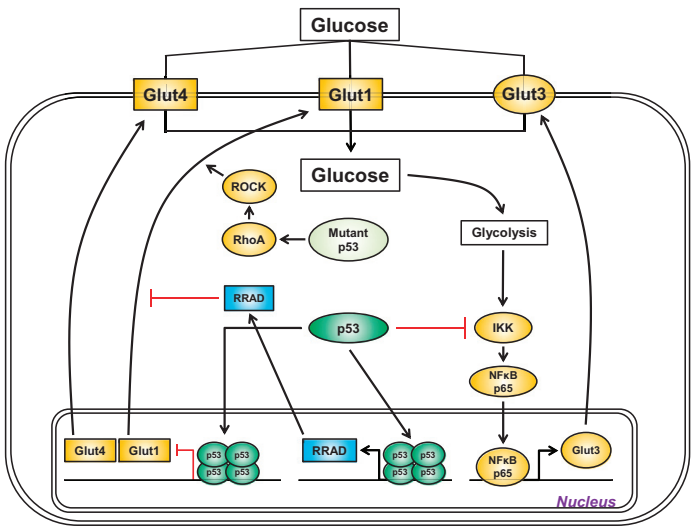

B

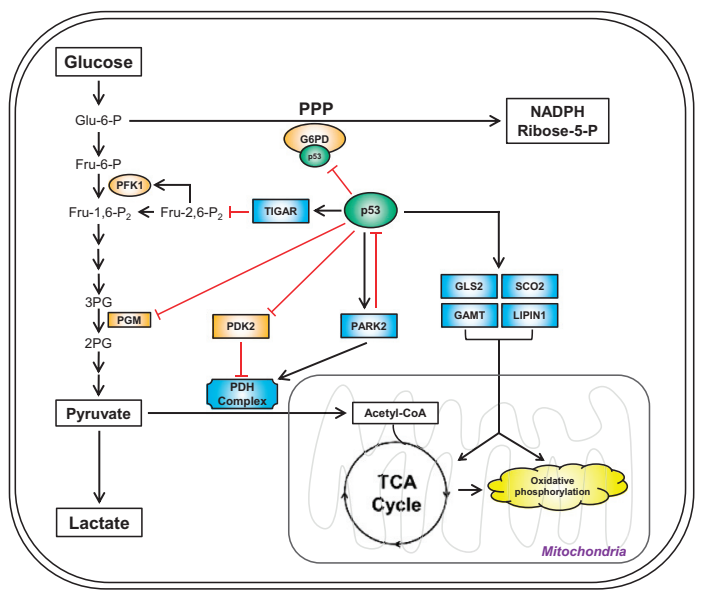

C

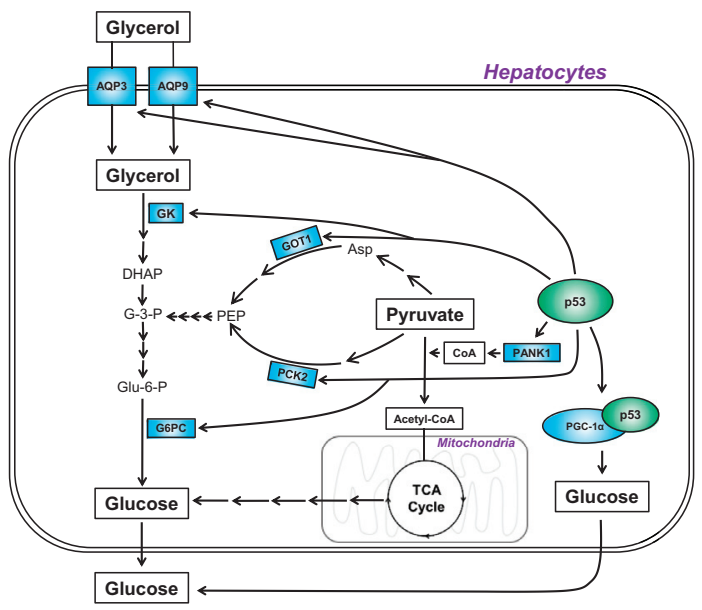

Figure 3

Three pathways for the $\mathrm{p} 53$-mediated regulation of glucose homeostasis. Wild-type p53 generally functions to induce circulating glucose level by (A) suppressing glucose uptake, (B) inhibiting aerobic glycolysis and (C) promoting gluconeogenesis. The genes in squares represent transcriptional targets of p53. In (A), the genes colored in orange and blue represent positive and negative regulators of glucose uptake, respectively. In (B), the genes colored in orange and blue represent positive and negative regulators of glycolysis. In (C), the genes colored in blue represent positive regulators of gluconeogenesis. $\mathrm{PDH}$, pyruvate dehydrogenase; PG, phosphoglycerate; PPP, pentose phosphatase pathway; TCA cycle, the citric acid cycle.

Published by Bioscientifica Ltd 
as the common 'hotspot' mutants R175H and R273H, can induce the Warburg effect by promoting translocation of GLUT1 to the plasma membrane (Zhang et al. 2013). This pathway is mediated by activation of the GTPases RhoA and ROCK. Conversely, wild-type p53 negatively regulates GLUT1 translocation to the plasma membrane by virtue of its ability to transcriptionally induce the p53 target gene RRAD (Zhang et al. 2014). Interestingly, $R R A D$ was first identified as a gene upregulated in tissues of type 2 diabetics, and overexpression of RRAD impairs glucose uptake and results in insulin resistance in muscle and fat tissues (Reynet \& Kahn 1993, Moyers et al. 1996). In sum, wild-type p53 negatively regulates, and mutant p53 positively regulates, glucose transporters and glucose import.

p53 negatively regulates glycolysis p53 influences glucose levels by directly regulating both its degradation (glycolysis) and synthesis (gluconeogenesis). Following DNA damage, p53 can reprogram the cell's energyproducing strategies from glycolysis to mitochondrial respiration (or oxidative phosphorylation) in order to suppress tumor progression (Fig. 3B). The first p53 target gene identified to inhibit glycolysis is TIGAR (TP53induced glycolysis and apoptosis regulator) (Bensaad et al. 2006). Overexpression of TIGAR lowers the level of fructose-2,6-bisphosphate (Fru-2,6- $\mathrm{P}_{2}$ ), which activates the glycolysis stimulator PFK1 (6-phosphofructo-1kinase). p53 also negatively regulates the stability of phosphoglycerate mutase (PGM), another enzyme critical for the completion of glycolysis by converting 3-phosphoglycerate (3-PG) to 2-phosphoglycerate (2-PG) (Kondoh et al. 2005). Analysis of the pentose phosphate pathway (PPP), an alternative mechanism to consume glucose for energy production, showed that it is blocked by $\mathrm{p} 53$, in part through direct interaction between p53 and the rate-limiting enzyme, glucose 6-phosphate dehydrogenase (G6PD) (Jiang et al. 2011). p53 also negatively regulates pyruvate dehydrogenase kinase-2 (PDK2) through both transcriptional and posttranslational pathways to activate the $\mathrm{PDH}$ complex, which converts pyruvate to acetyl-CoA to tip the balance from glycolysis to mitochondrial respiration (Kolobova et al. 2001, Contractor \& Harris 2012). Finally, p53 transactivates Parkin (PARK2), a gene associated with Parkinson's disease, in order to inhibit glycolysis (Zhang et al. 2011). Parkin inhibits glycolysis by positively regulating the expression level of PDHA1, which is the catalytic subunit of the PDH complex (Palacino et al. 2004).
There are other ways that p53 negatively regulates glycolysis. For example, p53 transcriptionally induces target genes that favor mitochondrial respiration: these include SCO2, GLS2, GAMT and LIPIN1 (Matoba et al. 2006, Ide et al. 2009, Hu et al. 2010, Assaily et al. 2011). It has also been suggested that p53 can indirectly control glycolysis by regulating the mammalian target of rapamycin (mTOR) and PI3K/Akt pathways. Specifically, these pathways are negatively regulated by the p53 target genes AMPK-B, Sestrin-1/2, TSC-2, REDD1 (which negatively regulate the mTOR pathway), and IGF-BP3 and PTEN (which negatively regulate the PI3K/AKT pathway) (see review by Liang et al. 2013). Finally, p53 regulates the expression of enzymes important for glucose uptake or glycolysis, including hexokinase-2 and phosphoglycerate mutase, PGM (Mathupala et al. 1997, Ruiz-Lozano et al. 1999). In the case of PGM, p53-mediated induction of PGM is muscle-specific, suggesting that tissue-specific functions of p53 exist within the context of glucose homeostasis regulation (Ruiz-Lozano et al. 1999, Kondoh et al. 2005).

p53 positively regulates gluconeogenesis Recent studies have uncovered a direct way for p53 to increase the level of glucose, by promoting gluconeogenesis (Fig. 3C). In an attempt to define p53-regulated metabolic pathways in liver-derived HepG2 cells using microarray analysis, Goldstein et al. identified multiple p53 target genes involved in the synthesis of glucose (Goldstein et al. 2013). They showed that activation of p53 by nutlin-3a, a compound that stabilizes $\mathrm{p} 53$ by virtue of its ability to inhibit MDM2, causes the increased expression of genes involved in gluconeogenesis (G6PC, PCK2) and in the supply of glucogenic precursors (GK, AQP3, AQP9 and GOT1). Moreover, this group found that active p53 augments hepatic glucose production in both HepG2 cells and primary mouse hepatocytes in glucogenic medium. p53-mediated induction of gluconeogenic enzymes in the liver was also shown in the Ay transgenic mouse model, which develops dietary obesity and diabetes, providing physiological relevance for p53-regulated gluconeogenesis in diabetes development (Minamino et al. 2009).

To identify the mechanisms underlying p53's ability to induce gluconeogenesis, two separate groups used p53-deficient mice as tools, and found that these mice displayed reduced glucogenic capacity compared with wild-type mice in response to metabolic stress, such as starvation. Sen and colleagues found that p53 forms a complex with the transcriptional cofactor peroxisome proliferator-activated receptor gamma coactivator 1

Published by Bioscientifica Ltd. 
alpha (PGC-1 $\alpha$ ) to facilitate the gluconeogenesis-related transcriptional machinery (Sen et al. 2011). Another group showed that p53 directly transactivates pantothenate kinase-1 (PANK1) to promote gluconeogenesis in the liver (Wang et al. 2013).

\section{p53 regulates insulin resistance}

Insulin resistance is the most reliable indicator of prediabetes and type 2 diabetes (Samuel \& Shulman 2012), and p53 regulates insulin resistance in a number of ways (Fig. 4). Many years ago, it was discovered that p53 negatively regulates the transcription of the insulin receptor (Webster et al. 1996). This was the first clue that p53 could influence insulin signaling directly. Impaired insulin sensitivity is accompanied by reduction of insulin signaling markers, including AKT phosphorylation, in peripheral tissues that are responsible for glucose uptake, such as adipose tissue, muscle, liver and brain. In rats fed with a high-fat diet, p53 was found to be activated in the peripheral tissues of obese rats that developed insulin resistance. As in the Ay mouse model of diabetes, an inhibitor of p53 was shown to ameliorate insulin resistance in this rat model (Homayounfar et al. 2015).

p53 in the adipose tissue Increased expression and activity of p53 is well known to occur in the adipocytes of obese mice (Yahagi et al. 2003). As mentioned above, in Ay transgenic mice fed with a high-fat/sucrose diet, p53-mediated senescence in adipose tissue is critical for the development of diabetes-like phenotypes and insulin resistance (Minamino et al. 2009). p53mediated senescence in adipose tissue is correlated with increased expression of $\mathrm{p} 21 / \mathrm{Cdkn} 1 \mathrm{~A}$ and proinflammatory cytokines, as well as decreased expression of anti-inflammatory cytokines. This group showed that adipose tissue-specific overexpression of p53 influences liver functions by regulating the expression of gluconeogenic enzymes in a paracrine fashion. The same group later found that p53-mediated chronic inflammation in adipose tissue leads to cardiac failure, signifying a connection between insulin resistance/ diabetes and cardiovascular disease (Shimizu et al. 2012). Using a diet-induced obesity (DIO) mouse model, this group went on to show that 553 regulates adipose tissue inflammation and insulin resistance by virtue, in part, of transactivation of class 3 semaphorin E (Sema3E), which acts as a chemoattractant to promote infiltration of macrophages (Shimizu et al. 2013).

A recent study suggests the convergence of p53 and the growth hormone $(\mathrm{GH})$ pathway in adipose tissue during the development of insulin resistance. In response to a high-fat diet, p53 expression in adipose tissue is increased through activation of p38MAPK; the latter

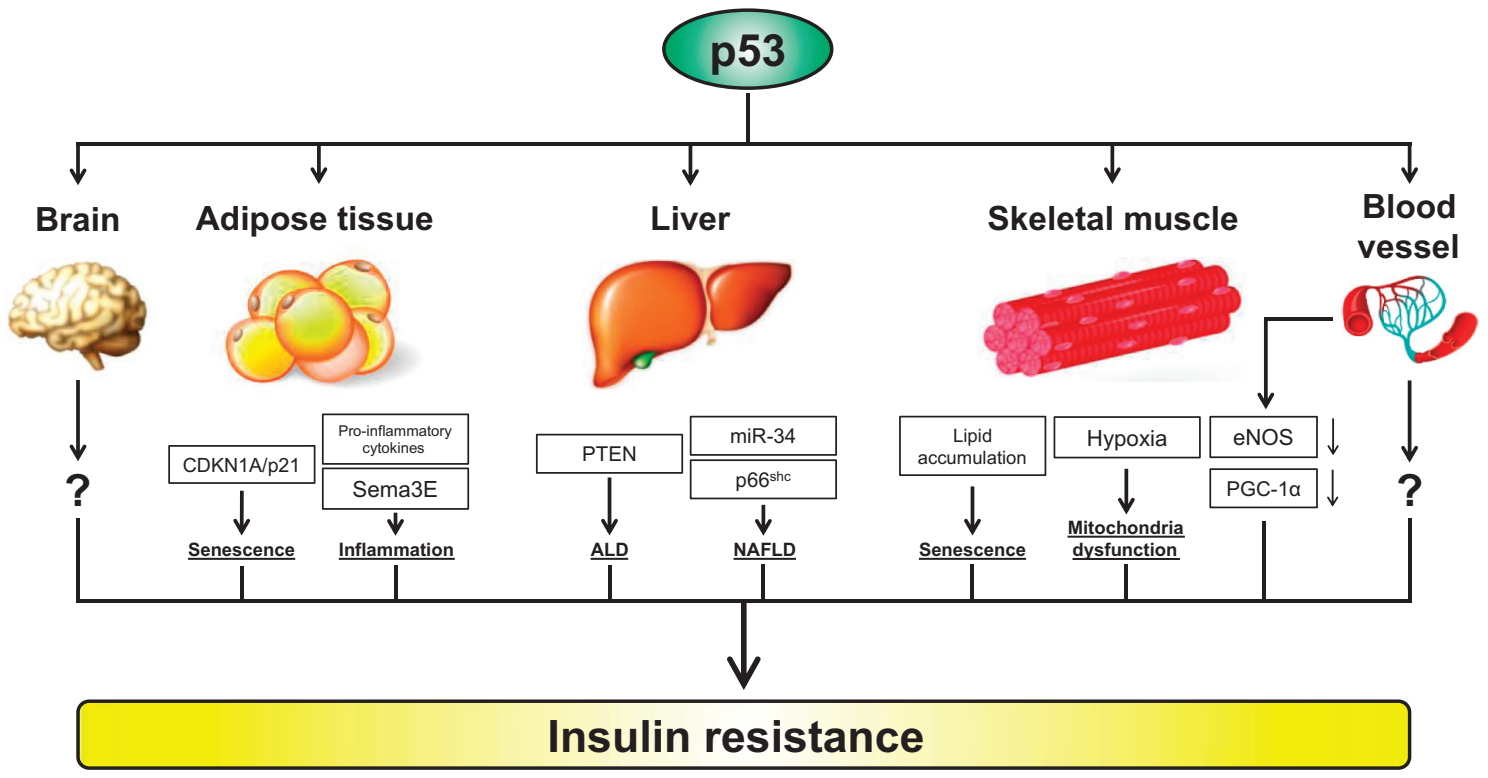

\section{Figure 4}

The regulation of insulin resistance by p53. The activation of p53 induces insulin resistance through multiple tissues/organs, including adipose tissue, liver, skeletal muscle, endothelial cells and the brain. Cross talk between these tissues also occurs, for example, endothelial cell-mediated insulin resistance in the skeletal muscle occurs via reduction in the former eNOS and PGC-1 $\alpha$. ALD, alcoholic liver disease; NAFLD, non-alcoholic fatty liver disease.

http://joe.endocrinology-journals.org DOI: 10.1530/JOE-16-0324
๑) 2016 Society for Endocrinology Printed in Great Britain
Published by Bioscientifica Ltd 
can be inhibited by GH antagonists (Bogazzi et al. 2013). This finding provides a potential link between DIO and p53-mediated adipose tissue inflammation and insulin resistance. As mentioned previously, the role of p21/Cdkn1A in insulin resistance is thought to be due to its role in p53-mediated senescence. In an interesting study, however, Inoue et al. demonstrated that p21/CDKN1A is critical for maintaining obesity-induced insulin resistance by promoting adipocyte differentiation and hypertrophy (Inoue et al. 2008). This group showed that knockdown of p21/Cdkn1A in the adipose tissue of mice with DIO rendered these tissues susceptible to p53-induced apoptosis. These data suggest that inhibition of apoptosis, in addition to induction of p53-mediated senescence, may underlie the role of p21/CDKN1A in the development of insulin resistance.

p53 in the liver and skeletal muscle Hepatic steatosis, or fatty liver, is one of the most common manifestations of obesity and type 2 diabetes (Williams et al. 2013). Despite current uncertainty about whether hepatic steatosis alone is sufficient to drive insulin resistance, there is little doubt that steatosis-mediated liver dysfunction significantly contributes to diabetic phenotypes (Gruben et al. 2014). Taking advantage of transgenic mouse models, Yahagi et al. showed that activation of p53 plays an important role in the pathogenesis of fatty liver disease, regardless of the status of obesity (Yahagi et al. 2004). Similarly, Derdak et al. demonstrated that activation of p53 enhances hepatic steatosis and insulin resistance in both alcoholic liver disease (ALD) and non-alcoholic fatty liver disease (NAFLD); notably, this group found that both ALD and NAFLD can be ameliorated by inhibiting p53 activity (Derdak et al. 2011, 2013). These studies also offered possible mechanistic underpinnings, and suggested that p53-mediated induction of PTEN and miRNA34a are responsible for the development of ALD and NAFLD, respectively. Using p53-knockout mice, another group confirmed a role for p53 in the progression of NAFLD, potentially through its downstream target $\mathrm{p} 66^{\text {shc }}$ (Tomita et al. 2012). It is important to note that these phenotypes observed in mouse models are physiologically relevant, as the level of steatosis and p53 expression are positively correlated in human liver samples (Panasiuk et al. 2006).

It is believed that impaired lipid oxidation and increased lipid accumulation are instrumental in promoting insulin resistance in the muscle (Eckardt et al. 2011). Moreover, expression of p53 is elevated in skeletal muscle of aged rodents, implicating the role of p53-mediated senescence in skeletal muscle functions
(Zwetsloot et al. 2013). Consistent with these theories, Jadhav and coworkers found that lipid byproduct, ceramide, is able to induce p53-mediated senescence and inhibit insulin signaling in myoblast cells (Jadhav et al. 2013). The roles of p53 in regulating mitochondrial function and oxidative stress are well documented (PuzioKuter 2011). In Goto-Kakizaki rats that develop early insulin resistance and type 2 diabetes, exercise training decreased p53 protein levels and restored mitochondrial function in skeletal muscle (Qi et al. 2011). These findings suggested that, in the context of diabetes, p53 might contribute positively to the development of insulin resistance through inducing oxidative stress in skeletal muscles. Consistent with this hypothesis, p53 was found to be an important target to control peripheral artery disease (PAD), which is an ischemic limb syndrome strongly associated with type 2 diabetes (Morimoto et al. 2011). Deferoxamine (DFX), a hypoxia mimetic and iron chelator, was used to mimic PAD in vitro and found to promote p53 accumulation in myoblast cells by suppressing MDM2 expression (Morimoto et al. 2011).

Other tissues and pathways involved in p53mediated insulin resistance The contribution of p53 to insulin resistance in other tissues was rarely studied until recently. Although not known as one of the main tissues to uptake glucose, dysfunctional microvascular tissue has been linked to the development of insulin resistance in obese and diabetic patients (Muris et al. 2012). Impaired insulin signaling in endothelial cells is believed to promote insulin resistance by reducing blood flow and glucose-uptake capability of skeletal muscle (Clark et al. 2003, Kubota et al. 2011). Moreover, vascular p53 is activated as a transcription factor in diabetic patients (Orimo et al. 2009). A direct connection between vascular p53 and insulin resistance was not uncovered until 2014, when Yokoyama et al. showed that in mice fed with a high-calorie diet, endothelial p53 promotes insulin resistance by suppressing the expression of endothelial nitric oxide synthase (eNOS) and peroxisome proliferatoractivated receptor- $\gamma$ coactivator- $1 \alpha$ (PGC- $1 \alpha)$ in skeletal muscle (Yokoyama et al. 2014).

It is possible that p53 also impacts insulin sensitivity through other mechanisms, such as obesity. Obesity is a strong risk factor for type 2 diabetes and insulin resistance (Wang et al. 2005). p53 transcriptionally regulates many genes associated with lipid metabolism (Goldstein \& Rotter 2012, Goldstein et al. 2012). Whether p53-mediated regulation of lipid-controlling genes plays a direct role in obesity remains to be determined. Recent evidence

Published by Bioscientifica Ltd 
suggests that p53 might influence obesity by controlling food intake. Velasquez et al. showed that p53-deficient mice failed to respond to the 'hunger hormone' ghrelin to induce food intake (Velasquez et al. 2011). This group posited that hypothalamic p53 is essential to mediate the orexigenic action of ghrelin. A later study showed that p53, by altering the expression levels of lipogenic and adipogenic genes, is necessary for ghrelin-mediated lipid storage in fat and liver (Porteiro et al. 2013). These combined studies implicate p53 as a potentially important player in the regulation of feeding behavior and obesity. Interestingly, as if it serves to counteract the 'obesity-driving' functions of p53, it was shown that p53 in the brown adipose tissue protects against DIO (Molchadsky et al. 2013). Therefore, the role of p53 in obesity may be tissue-specific.

There is some information available concerning the role of posttranslational modifications of p53 on insulin sensitivity. For example, Ser15 phosphorylation of p53 (equivalent to Ser18 in mouse) is the most commonly used indicator for p53 activation (Banin et al. 1998). Mutation at this site was predicted to inhibit p53's ability to induce apoptosis or cell cycle arrest. Interestingly, however, mice possessing the Ser18 to alanine mutation did not display significant changes in growth arrest or apoptosis, but rather displayed phenotypes of impaired glucose homeostasis and increased insulin resistance (Armata et al. 2010). Notably, this phenotype mimics the metabolic syndrome seen in ataxia telangiectasia patients, who possess mutations in the p53 Ser15 kinase, ATM.

\section{p53 lies both upstream and downstream of a key regulator of metabolic stress, AMPK}

A master regulator of metabolism is the mTOR, which is a member of the phosphatidylinositol 3-kinase-related kinase protein family. It is a serine/threonine protein kinase that positively regulates protein synthesis, cell growth and proliferation, and negatively regulates autophagy, which is a key catabolic pathway that is activated under conditions of nutrient starvation (Shaw \& Cantley 2006). The p53 tumor suppressor negatively regulates $\mathrm{mTOR}$ in part by transactivating its negative regulator, AMPK (5' AMP-activated protein kinase). In response to DNA damage, p53 directly transactivates the beta 1 and beta2 subunits of AMPK, as well as other negative regulators of $\mathrm{mTOR}$, including the tuberous sclerosis complex protein TSC2, and the phosphatase PTEN (Feng et al. 2007). All of these can inhibit mTOR activity, and therefore lead to growth cessation and induction of autophagy. Additionally, p53 transcriptionally regulates the genes Sestrin1 and Sestrin2; the protein product of these genes binds to and activates AMPK, which in turn phoshophorylates TSC2 and consequently inhibits mTOR. The loss of Sestrin2 during nutrient deprivation (Budanov \& Karin 2008) or pharmacological inhibition of AMPK (Feng et al. 2005) both significantly reduce p53-mediated inhibition of mTOR.

In normal healthy cells, p53 is kept at low levels by the E3 ubiquitin ligase MDM2 (HDM2 in mice), which ubiquitylates p53 and targets it for proteasomal degradation. In response to various forms of stress, phosphorylation of the amino terminus of p53 prevents interaction with MDM2, leading to p53 stabilization. Metabolic stress (nutrient deprivation) is known to induce p53 through phosphorylation on serine 15 mediated by the kinase AMPK, which responds to low AMP levels following ATP depletion. Once activated, p53 transactivates gene involved in cell cycle arrest and apoptosis, thereby eliminating cells with prolonged activation of AMPK (Jones et al. 2005, Feng et al. 2007).

\section{Polymorphisms in the p53 pathway: the codon 72 polymorphism of p53}

Genetic polymorphisms arise over time and can undergo natural selection. Among these, some SNPs can significantly affect biological functions. In the context of p53, a common SNP occurs at amino acid 72, where nucleotide sequence CCC or CGC encodes for proline (P72) or arginine (R72), respectively (rs1042522; P72R). This polymorphism can have significant impact on p53 function. In response to DNA damage, the P72 variant has been shown to promote a stronger cell cycle arrest phenotype, while the R72 variant is a superior inducer of apoptosis (Dumont et al. 2003, Kung et al. 2015), although tissue-specific differences to these phenotypes have been observed (Azzam et al. 2011). The impact of the codon 72 polymorphism on metabolic disease was not well studied, until recent reports linked this p53 SNP to susceptibility to diabetes. It was first reported that the codon 72 polymorphism was associated with type 1 diabetes in a Russian population (Spitsina et al. 2007). Similar results were later found in an Italian cohort (Bitti et al. 2011). In 2008, the R72 variant was identified as one of the strongest risk factors in more than 2000 Finnish patients for type 2 diabetes (Gaulton et al. 2008). Using clinical data from over 55,000 Europeans, a subsequent meta-analysis study confirmed this finding, that the

Published by Bioscientifica Ltd. 
R72 variant was linked to type 2 diabetes (Burgdorf et al. 2011). Similar findings were made in the Chinese Han population, indicating that R72 increased susceptibility to type 2 diabetes is not a race-restricted phenomenon (Qu et al. 2011). Finally, the R72 variant is associated with increased insulin resistance, even among diabetes patients (Bonfigli et al. 2013).

A cohort study of over 2500 Dutch and Finnish subjects found that the R72 variant is associated with increased waist circumference (Reiling et al. 2012). These data suggested that the R72 variant might predispose individuals to adiposity/obesity, and that this might then lead to increased risk for the development of type 2 diabetes. A recent GWAS (genome-wide association study) found that the R72 variant of p53 is associated with increased body mass index (BMI) (Speliotes et al. 2010). Consistent with these reports, a separate study showed that the association between BMI and diabetes incidence is much stronger in individuals of the R72 genotype (Gloria-Bottini et al. 2011). Recently, our group used a mouse model for the codon 72 polymorphism of p53 in order to investigate the role of this SNP in obesity and diabetes. To understand this role, we monitored these mice following challenge with a high-fat diet (HFD). Mice with the R72 variant of p53 developed more severe obesity and glucose intolerance on a HFD, compared with mice having the proline 72 variant (P72). R72 mice on a HFD developed insulin resistance, islet hypertrophy, increased infiltration of immune cells and fatty liver disease, but the earliest difference between R72 and P72 mice on a HFD was fat accumulation (obesity).
Gene expression analyses indicated that two p53 target genes, with roles in inflammation (Tnf) and cholesterol metabolism (Npc1l1), were in part responsible for this phenotype (Kung et al. 2016).

\section{Other polymorphisms in p53 pathway genes}

Several genetic polymorphisms in genes involved in p53 signaling pathways have been shown to affect p53 function (Whibley et al. 2009), and some of these may likewise affect diabetes risk or severity. The A17708T polymorphism of p53 intron 10 is associated with the development of early uremic complications in diabetic patients (Szoke et al. 2009). A recent GWAS in type 2 diabetic patients identified a SNP in ATM (rs11212617) that controls treatment response to metformin, the most commonly used drug for type 2 diabetes (GoDarts et al. 2011). The authors suggested that this ATM variant might affect metformin efficacy by regulating downstream target of metformin, AMPK (AMP-activated protein kinase). ATM is an important regulator of p53, and ATM SNPs have been shown to affect p53 function (Takagi et al. 2004). As noted above, p53 activity is regulated by AMPK (Jones et al. 2005). Therefore, it is possible that p53 plays an active role in the impact of rs11212617 on the glycemic response to metformin.

As mentioned previously, the $\mathrm{T}$ allele of TCF7L2 (rs7903146) confers the strongest risk for type 2 diabetes known in Caucasians (Florez 2007). TCF7L2 serves a unique dual role in the p53 pathway, as it serves both as a regulatory transcription factor for $\mathrm{p} 53$, and a

Table 1 p53 pathway SNPs and diabetes.

$\begin{array}{lllll}\text { Gene } & \text { SNP (allele) } & & \text { MAFa }^{\text {TP53 }} & \text { Relationship with p53 } \\ \text { rs1042522 (C> G) } & 0.46(\mathrm{C}) & \end{array}$

\section{Impact}

G allele (Arg72) is a risk factor for obesity and diabetes
TP53 $\quad r s 17880847(A>T) \quad 0.01(T)$

$\begin{array}{llrl}\text { TCF7L2 } & \text { rs7903146 (C> T) } & 0.23(\mathrm{~T}) & \begin{array}{c}\text { Transcription factor and } \\ \text { transcriptional target }\end{array} \\ \text { P53INP1 } & \text { rs896854 (T > C) } & 0.48(\mathrm{~T}) & \text { Transcriptional target } \\ \text { ATM } & \text { rs11212617 (C>A) } & 0.47 \text { (A) } & \text { Activator }\end{array}$

T allele predisposes to uremic complications in diabetic patients

T allele is a risk factor for diabetes in Caucasians

$C$ allele is a risk factor for diabetes

Regulates treatment response to metformin

\section{References \\ Spitsina et al. (2007), Gaulton et al. (2008), Bitti et al. (2011), Burgdorf et al. (2011), Gloria-Bottini et al. (2011), Qu et al. (2011), Reiling et al. (2012), Bonfigli et al. (2013) Szoke et al. (2009)}

Florez (2007)

Voight et al. (2010)

GoDarts et al. (2011)

aSource: Genome 1000 project database (1000genomes.org). MAF, minor allele frequency; SNP, single-nucleotide polymorphism. 
transcriptional target of p53 (Rother et al. 2004, Zhou et al. 2012). TCF7L2 regulates the expression of p53 and the p53 target gene p53INP1 to control the survival of pancreatic beta cells. Interestingly, a SNP in p53INP1 (rs896854) has also recently been identified as a type 2 diabetes susceptibility locus through a large-scale GWAS project (Voight et al. 2010) (Table 1). The overall data suggest that multiple SNPs in p53 and in genes involved in the p53 pathway can be predicted to play roles in metabolism and diabetes.

\section{p53 and the efficacy of diabetes treatment}

The magnitude of the impact of diabetes on human health is often characterized by its associated complications, such as cardiovascular diseases, impaired wound healing, nephropathy, blindness and infertility (Brownlee 2005). In addition to its roles in diabetes risk and severity, p53 has also been shown to play an active role in these conditions by regulating apoptosis, cell cycle arrest, senescence and inflammation (Jazayeri et al. 2008, Nguyen et al. 2010, Morimoto et al. 2011, Zhao et al. 2011, Samarakoon et al. 2012, Gurel et al. 2014). Targeting p53 to treat diabetes potentially offers extra benefits as an inclusive approach to alleviate both diabetes and downstream symptoms. The majority of studies outlined in this review have shown that inhibiting p53 using gene silencing, knockout or pharmacological approaches can alleviate diabetes and its phenotypes; however, this trend has not been consistent. For example, nutlin-3a, a non-genotoxic activator of p53 that works via inhibition of the MDM2-p53 interaction, was able to improve pancreatic function and glucose homeostasis in a streptozotocin-induced mouse model of diabetes (Secchiero et al. 2013). Similarly, targeting the peroxisome proliferator-activated receptor- $\gamma$ (PPAR $\gamma$ ) has been a proven strategy for the drug development against obesity and diabetes (Blaschke et al. 2006). PPAR $\gamma$ forms a heterodimer with retinoid $X$ receptor (RXR), and PPAR $\gamma /$ RXR complexes can be targeted by RXR antagonists to confer antiobesity and antidiabetic activities (Yamauchi et al. 2001). Nakatsuka et al. showed that the RXR antagonist HX531 upregulated the p53-p21/CDKN1A pathway in adipocytes to induce cell cycle arrest and inhibit cellular hypertrophy that could otherwise lead to obesity (Nakatsuka et al. 2012). Therefore, the therapeutic benefit of inhibiting or inducing p53 is likely to be influenced by cell type and stage of disease.

\section{Conclusions}

Given the magnitude of evidence presented in this review, it is clear that p53 is a key player in diabetes and the severity of diabetic phenotypes. For the most part, it is activation of p53 that was shown to exacerbate diabetic phenotypes. For example, this protein is induced and activated in many cell types in animals and humans with diabetes, and in many cases pharmacological inhibition of p53 led to an amelioration of diabetic phenotypes. However, clearly the role of p53 in diabetes is complex, and in some settings, activation of p53 has been shown to be beneficial to disease outcome (Secchiero et al. 2013). Therefore, despite the magnitude of evidence suggesting that inhibitors of p53 might ameliorate diabetes, it is clearly premature to propose this avenue. Rather, identifying the key pathways and target genes controlled by p53, and targeting these, might be more advisable. Along these lines, in a DIO model of diabetes, we identified the p53 target genes Tnf (Tnf-alpha) and Npc1l1 (controls cholesterol metabolism) as markedly induced by p53 after as little as 7 days on a HFD. Notably, we found that the use of antibody or smallmolecule inhibitors to either of these proteins caused reduced fat accumulation and ameliorated diabetic phenotypes (Kung et al. 2016). Therefore, there may be more merit in the complete identification of p53 target genes that are specifically induced in diabetic tissues, with the goal of targeting these genes for therapy.

\section{Declaration of interest}

The authors declare that there is no conflict of interest that could be perceived as prejudicing the impartiality of this review.

\section{Funding}

This work was supported by the NIH (R01 CA102184 and CA201430 to M M).

\section{Acknowledgements}

The authors thank Subhasree Basu and Thibaut Barnoud for critical reading of this manuscript.

\section{References}

Armata HL, Golebiowski D, Jung DY, Ko HJ, Kim JK \& Sluss HK 2010 Requirement of the ATM/p53 tumor suppressor pathway for glucose homeostasis. Molecular and Cellular Biology 30 5787-5794. (doi:10.1128/MCB.00347-10)

Assaily W, Rubinger DA, Wheaton K, Lin Y, Ma W, Xuan W, BrownEndres L, Tsuchihara K, Mak TW \& Benchimol S 2011 ROS-mediated p53 induction of Lpin1 regulates fatty acid oxidation in response to nutritional stress. Molecular Cell 44 491-501. (doi:10.1016/j. molcel.2011.08.038)

Published by Bioscientifica Ltd 
Azzam GA, Frank AK, Hollstein M \& Murphy ME 2011 Tissue-specific apoptotic effects of the p53 codon 72 polymorphism in a mouse model. Cell Cycle 10 1352-1355. (doi:10.4161/cc.10.9.15344)

Banin S, Moyal L, Shieh S, Taya Y, Anderson CW, Chessa L, Smorodinsky NI, Prives C, Reiss Y, Shiloh Y, et al. 1998 Enhanced phosphorylation of p53 by ATM in response to DNA damage. Science 281 1674-1677. (doi:10.1126/science.281.5383.1674)

Belgardt BF, Ahmed K, Spranger M, Latreille M, Denzler R, Kondratiuk N, von Meyenn F, Villena FN, Herrmanns K, Bosco D, et al. 2015 The microRNA-200 family regulates pancreatic beta cell survival in type 2 diabetes. Nature Medicine 21 619-627. (doi:10.1038/nm.3862)

Bensaad K, Tsuruta A, Selak MA, Vidal MN, Nakano K, Bartrons R, Gottlieb E \& Vousden KH 2006 TIGAR, a p53-inducible regulator of glycolysis and apoptosis. Cell 126 107-120. (doi:10.1016/ j.cell.2006.05.036)

Berkers CR, Maddocks OD, Cheung EC, Mor I \& Vousden KH 2013 Metabolic regulation by p53 family members. Cell Metabolism 18 617-633. (doi:10.1016/j.cmet.2013.06.019)

Bitti ML, Saccucci P, Capasso F, Piccinini S, Angelini F, Rapini N, Porcari M, Arcano S, Petrelli A, Del Duca E, et al. 2011 Genotypes of p53 codon 72 correlate with age at onset of type 1 diabetes in a sex-specific manner. Journal of Pediatric Endocrinology and Metabolism 24 437-439. (doi:10.1515/jpem.2011.058)

Blaschke F, Takata Y, Caglayan E, Law RE \& Hsueh WA 2006 Obesity, peroxisome proliferator-activated receptor, and atherosclerosis in type 2 diabetes. Arteriosclerosis, Thrombosis, and Vascular Biology 26 28-40. (doi:10.1161/01.ATV.0000191663.12164.77)

Bogazzi F, Raggi F, Russo D, Bohlooly YM, Sardella C, Urbani C, Lombardi M, Manetti L, Lupi I, Tornell J, et al. 2013 Growth hormone is necessary for the p53-mediated, obesity-induced insulin resistance in male C57BL/6J x CBA mice. Endocrinology 154 4226-4236. (doi:10.1210/en.2013-1220)

Bonfigli AR, Sirolla C, Testa R, Cucchi M, Spazzafumo L, Salvioli S, Ceriello A, Olivieri F, Festa R, Procopio AD, et al. 2013 The p53 codon 72 (Arg72Pro) polymorphism is associated with the degree of insulin resistance in type 2 diabetic subjects: a cross-sectional study. Acta Diabetologica 50 429-436. (doi:10.1007/s00592-012-0450-x)

Bourdon JC, Fernandes K, Murray-Zmijewski F, Liu G, Diot A, Xirodimas DP, Saville MK \& Lane DP 2005 p53 isoforms can regulate p53 transcriptional activity. Genes \& Development 19 2122-2137. (doi:10.1101/gad.1339905)

Brady CA, Jiang D, Mello SS, Johnson TM, Jarvis LA, Kozak MM, Kenzelmann Broz D, Basak S, Park EJ, McLaughlin ME, et al. 2011 Distinct p53 transcriptional programs dictate acute DNA-damage responses and tumor suppression. Cell 145 571-583. (doi:10.1016/j.cell.2011.03.035)

Brownlee M 2005 The pathobiology of diabetic complications: a unifying mechanism. Diabetes 54 1615-1625. (doi:10.2337/diabetes.54.6.1615)

Budanov AV \& Karin M 2008 p53 target genes sestrin1 and sestrin2 connect genotoxic stress and mTOR signaling. Cell 134 451-460. (doi:10.1016/j.cell.2008.06.028)

Burgdorf KS, Grarup N, Justesen JM, Harder MN, Witte DR, Jorgensen T, Sandbaek A, Lauritzen T, Madsbad S, Hansen T, et al. 2011 Studies of the association of Arg72Pro of tumor suppressor protein p53 with type 2 diabetes in a combined analysis of 55,521 Europeans. PLOS ONE 6 e15813. (doi:10.1371/journal.pone.0015813)

Chang JR, Ghafouri M, Mukerjee R, Bagashev A, Chabrashvili T \& Sawaya BE 2012 Role of p53 in neurodegenerative diseases. Neuro-degenerative Diseases 9 68-80. (doi:10.1159/000329999)

Cherrington AD 1999 Banting Lecture 1997. Control of glucose uptake and release by the liver in vivo. Diabetes 48 1198-1214. (doi:10.2337/ diabetes.48.5.1198)

Clark MG, Wallis MG, Barrett EJ, Vincent MA, Richards SM, Clerk LH \& Rattigan S 2003 Blood flow and muscle metabolism: a focus on insulin action. American Journal of Physiology. Endocrinology and Metabolism 284 E241-E258. (doi:10.1152/ ajpendo.00408.2002)
Cnop M, Welsh N, Jonas JC, Jorns A, Lenzen S \& Eizirik DL 2005 Mechanisms of pancreatic beta-cell death in type 1 and type 2 diabetes: many differences, few similarities. Diabetes 54 (Supplement 2) S97-S107. (doi:10.2337/diabetes.54.suppl_2.S97)

Contractor T \& Harris CR 2012 p53 negatively regulates transcription of the pyruvate dehydrogenase kinase Pdk2. Cancer Research 72 560-567. (doi:10.1158/0008-5472.CAN-11-1215)

Danilova N, Sakamoto KM \& Lin S 2008 p53 family in development. Mechanisms of Development 125 919-931. (doi:10.1016/j. mod.2008.09.003)

Derdak Z, Lang CH, Villegas KA, Tong M, Mark NM, de la Monte SM \& Wands JR 2011 Activation of p53 enhances apoptosis and insulin resistance in a rat model of alcoholic liver disease. Journal of Hepatology 54 164-172. (doi:10.1016/j.jhep.2010.08.007)

Derdak Z, Villegas KA, Harb R, Wu AM, Sousa A \& Wands JR 2013 Inhibition of p53 attenuates steatosis and liver injury in a mouse model of non-alcoholic fatty liver disease. Journal of Hepatology $\mathbf{5 8}$ 785-791. (doi:10.1016/j.jhep.2012.11.042)

Dumont P, Leu JI, Della Pietra AC 3rd, George DL \& Murphy M 2003 The codon 72 polymorphic variants of p53 have markedly different apoptotic potential. Nature Genetics 33 357-365. (doi:10.1038/ ng1093)

Eckardt K, Taube A \& Eckel J 2011 Obesity-associated insulin resistance in skeletal muscle: role of lipid accumulation and physical inactivity. Reviews in Endocrine \& Metabolic Disorders 12 163-172. (doi:10.1007/ s11154-011-9168-2)

Feng Z, Zhang H, Levine AJ \& Jin S 2005 The coordinate regulation of the p53 and mTOR pathways in cells. PNAS 102 8204-8209. (doi:10.1073/pnas.0502857102)

Feng Z, Hu W, de Stanchina E, Teresky AK, Jin S, Lowe S \& Levine AJ 2007 The regulation of AMPK beta1, TSC2, and PTEN expression by p53: stress, cell and tissue specificity, and the role of these gene products in modulating the IGF-1-AKT-mTOR pathways. Cancer Research 67 3043-3053. (doi:10.1158/0008-5472.CAN-06-4149)

Florez JC 2007 The new type 2 diabetes gene TCF7L2. Current Opinion in Clinical Nutrition and Metabolic Care 10 391-396. (doi:10.1097/ MCO.0b013e3281e2c9be)

Gaulton KJ, Willer CJ, Li Y, Scott LJ, Conneely KN, Jackson AU, Duren WL, Chines PS, Narisu N, Bonnycastle LL, et al. 2008 Comprehensive association study of type 2 diabetes and related quantitative traits with 222 candidate genes. Diabetes 57 3136-3144. (doi:10.2337/db07-1731)

Gloria-Bottini F, Banci M, Saccucci P, Magrini A \& Bottini E 2011 Is there a role of p53 codon 72 polymorphism in the susceptibility to type 2 diabetes in overweight subjects? A study in patients with cardiovascular diseases. Diabetes Research and Clinical Practice 91 e64-e67. (doi:10.1016/j.diabres.2010.11.031)

GoDarts, Group UDPS, Wellcome Trust Case Control C, Zhou K, Bellenguez C, Spencer CC, Bennett AJ, Coleman RL, Tavendale R, Hawley SA, et al. 2011 Common variants near ATM are associated with glycemic response to metformin in type 2 diabetes. Nature Genetics 43 117-120. (doi:10.1038/ng.735)

Goldstein I \& Rotter V 2012 Regulation of lipid metabolism by p53 - fighting two villains with one sword. Trends in Endocrinology and Metabolism 23 567-575. (doi:10.1016/j.tem.2012.06.007)

Goldstein I, Ezra O, Rivlin N, Molchadsky A, Madar S, Goldfinger N \& Rotter V 2012 p53, a novel regulator of lipid metabolism pathways. Journal of Hepatology 56 656-662. (doi:10.1016/j.jhep. 2011.08.022)

Goldstein I, Yizhak K, Madar S, Goldfinger N, Ruppin E \& Rotter V 2013 p53 promotes the expression of gluconeogenesis-related genes and enhances hepatic glucose production. Cancer \& Metabolism 19 (doi:10.1186/2049-3002-1-9)

Grant SF, Thorleifsson G, Reynisdottir I, Benediktsson R, Manolescu A, Sainz J, Helgason A, Stefansson H, Emilsson V, Helgadottir A, et al. 2006 Variant of transcription factor 7-like 2 (TCF7L2) gene confers

Published by Bioscientifica Ltd. 
risk of type 2 diabetes. Nature Genetics 38 320-323. (doi:10.1038/ ng1732)

Gruben N, Shiri-Sverdlov R, Koonen DP \& Hofker MH 2014 Nonalcoholic fatty liver disease: a main driver of insulin resistance or a dangerous liaison? Biochimica et Biophysica Acta 1842 2329-2343. (doi:10.1016/ j.bbadis.2014.08.004)

Gurel Z, Zaro BW, Pratt MR \& Sheibani N 2014 Identification of O-GlcNAc modification targets in mouse retinal pericytes: implication of p53 in pathogenesis of diabetic retinopathy. PLOS ONE 9 e95561. (doi:10.1371/journal.pone.0095561)

Hinault C, Kawamori D, Liew CW, Maier B, Hu J, Keller SR, Mirmira RG, Scrable H \& Kulkarni RN 2011 Delta40 Isoform of p53 controls beta-cell proliferation and glucose homeostasis in mice. Diabetes 60 1210-1222. (doi:10.2337/db09-1379)

Homayounfar R, Jeddi-Tehrani M, Cheraghpour M, Ghorbani A \& Zand H 2015 Relationship of p53 accumulation in peripheral tissues of high-fat diet-induced obese rats with decrease in metabolic and oncogenic signaling of insulin. General and Comparative Endocrinology 214 134-139. (doi:10.1016/j.ygcen.2014.06.029)

Hoshino A, Ariyoshi M, Okawa Y, Kaimoto S, Uchihashi M, Fukai K, Iwai-Kanai E, Ikeda K, Ueyama T, Ogata T, et al. 2014 Inhibition of p53 preserves Parkin-mediated mitophagy and pancreatic betacell function in diabetes. PNAS 111 3116-3121. (doi:10.1073/ pnas.1318951111)

Hu W, Zhang C, Wu R, Sun Y, Levine A \& Feng Z 2010 Glutaminase 2, a novel p53 target gene regulating energy metabolism and antioxidant function. PNAS 107 7455-7460. (doi:10.1073/pnas.1001006107)

Ide T, Brown-Endres L, Chu K, Ongusaha PP, Ohtsuka T, El-Deiry WS, Aaronson SA \& Lee SW 2009 GAMT, a p53-inducible modulator of apoptosis, is critical for the adaptive response to nutrient stress. Molecular Cell 36 379-392. (doi:10.1016/j.molcel.2009. 09.031)

Inoue N, Yahagi N, Yamamoto T, Ishikawa M, Watanabe K, Matsuzaka T, Nakagawa Y, Takeuchi Y, Kobayashi K, Takahashi A, et al. 2008 Cyclin-dependent kinase inhibitor, p21WAF1/CIP1, is involved in adipocyte differentiation and hypertrophy, linking to obesity, and insulin resistance. Journal of Biological Chemistry 283 21220-21229. (doi:10.1074/jbc.M801824200)

Jadhav KS, Dungan CM \& Williamson DL 2013 Metformin limits ceramide-induced senescence in C2C12 myoblasts. Mechanisms of Ageing and Development 134 548-599. (doi:10.1016/j. mad.2013.11.002)

Jazayeri L, Callaghan MJ, Grogan RH, Hamou CD, Thanik V, Ingraham CR, Capell BC, Pelo CR \& Gurtner GC 2008 Diabetes increases p53-mediated apoptosis following ischemia. Plastic and Reconstructive Surgery 121 1135-1143. (doi:10.1097/01.prs. 0000302499.18738.c2)

Jiang P, Du W, Wang X, Mancuso A, Gao X, Wu M \& Yang X 2011 p53 regulates biosynthesis through direct inactivation of glucose-6-phosphate dehydrogenase. Nature Cell Biology 13 310-316. (doi:10.1038/ncb2172)

Jones RG, Plas DR, Kubek S, Buzzai M, Mu J, Xu Y, Birnbaum M \& Thompson CB 2005 AMP-activated protein kinase induces a p53-dependent metabolic checkpoint. Molecular Cell 18 283-293. (doi:10.1016/j.molcel.2005.03.027)

Karunakaran U, Kim HJ, Kim JY \& Lee IK 2012 Guards and culprits in the endoplasmic reticulum: glucolipotoxicity and beta-cell failure in type II diabetes. Experimental Diabetes Research 2012639762. (doi:10.1155/2012/639762)

Kawauchi K, Araki K, Tobiume K \& Tanaka N 2008 p53 regulates glucose metabolism through an IKK-NF-kappaB pathway and inhibits cell transformation. Nature Cell Biology 10 611-618. (doi:10.1038/ncb1724)

Kim WH, Lee JW, Gao B \& Jung MH 2005 Synergistic activation of JNK/SAPK induced by TNF-alpha and IFN-gamma: apoptosis of pancreatic beta-cells via the p53 and ROS pathway. Cellular Signalling 17 1516-1532. (doi:10.1016/j.cellsig.2005.03.020)

http://joe.endocrinology-journals.org

DOI: 10.1530/JOE-16-0324
() 2016 Society for Endocrinology Printed in Great Britain
Kolobova E, Tuganova A, Boulatnikov I \& Popov KM 2001 Regulation of pyruvate dehydrogenase activity through phosphorylation at multiple sites. Biochemical Journal 358 69-77. (doi:10.1042/ bj3580069)

Kon N, Zhong J, Qiang L, Accili D \& Gu W 2012 Inactivation of arf-bp1 induces p53 activation and diabetic phenotypes in mice. Journal of Biological Chemistry 287 5102-5111. (doi:10.1074/jbc. M111.322867)

Kondoh H, Lleonart ME, Gil J, Wang J, Degan P, Peters G, Martinez D, Carnero A \& Beach D 2005 Glycolytic enzymes can modulate cellular life span. Cancer Research 65 177-185.

Koshkin V, Wang X, Scherer PE, Chan CB \& Wheeler MB 2003 Mitochondrial functional state in clonal pancreatic beta-cells exposed to free fatty acids. Journal of Biological Chemistry 278 19709-19715. (doi:10.1074/jbc.M209709200)

Kubota T, Kubota N, Kumagai H, Yamaguchi S, Kozono H, Takahashi T, Inoue M, Itoh S, Takamoto I, Sasako T, et al. 2011 Impaired insulin signaling in endothelial cells reduces insulin-induced glucose uptake by skeletal muscle. Cell Metabolism 13 294-307. (doi:10.1016/ j.cmet.2011.01.018)

Kung CP, Budina A, Balaburski G, Bergenstock MK \& Murphy M 2011 Autophagy in tumor suppression and cancer therapy. Critical Reviews in Eukaryotic Gene Expression 21 71-100. (doi:10.1615/ CritRevEukarGeneExpr.v21.i1.50)

Kung CP, Khaku S, Jennis M, Zhou Y \& Murphy ME 2015 Identification of TRIML2, a novel p53 target, that enhances p53 SUMOylation and regulates the transactivation of proapoptotic genes. Molecular Cancer Research 13 250-262. (doi:10.1158/15417786.MCR-14-0385)

Kung CP, Leu JI, Basu S, Khaku S, Anokye-Danso F, Liu Q, George DL, Ahima RS \& Murphy ME 2016 The P72R polymorphism of p53 predisposes to obesity and metabolic dysfunction. Cell Reports $\mathbf{1 4}$ 2413-2425. (doi:10.1016/j.celrep.2016.02.037)

Las G \& Shirihai OS 2010 The role of autophagy in beta-cell lipotoxicity and type 2 diabetes. Diabetes, Obesity \& Metabolism 12 (Supplement 2) 15-19. (doi:10.1111/j.1463-1326.2010.01268.x)

Levine AJ \& Oren M 2009 The first 30 years of p53: growing ever more complex. Nature Reviews. Cancer 9 749-758. (doi:10.1038/ nrc2723)

Levine AJ, Tomasini R, McKeon FD, Mak TW \& Melino G 2011 The p53 family: guardians of maternal reproduction. Nature Reviews. Molecular Cell Biology 12 259-265. (doi:10.1038/nrm3086)

Li T, Kon N, Jiang L, Tan M, Ludwig T, Zhao Y, Baer R \& Gu W 2012 Tumor suppression in the absence of p53-mediated cell-cycle arrest, apoptosis, and senescence. Cell 149 1269-1283. (doi:10.1016/ j.cell.2012.04.026

Liang Y, Liu J \& Feng Z 2013 The regulation of cellular metabolism by tumor suppressor p53. Cell \& Bioscience 3 9. (doi:10.1186/20453701-3-9)

Lovis P, Roggli E, Laybutt DR, Gattesco S, Yang JY, Widmann C, Abderrahmani A \& Regazzi R 2008 Alterations in microRNA expression contribute to fatty acid-induced pancreatic beta-cell dysfunction. Diabetes 57 2728-2736. (doi:10.2337/db07-1252)

Madan E, Gogna R, Bhatt M, Pati U, Kuppusamy P \& Mahdi AA 2011 Regulation of glucose metabolism by p53: emerging new roles for the tumor suppressor. Oncotarget 2 948-957. (doi:10.18632/ oncotarget.389)

Mathupala SP, Heese C \& Pedersen PL 1997 Glucose catabolism in cancer cells. The type II hexokinase promoter contains functionally active response elements for the tumor suppressor p53. Journal of Biological Chemistry 272 22776-22780. (doi:10.1074/ jbc.272.36.22776)

Matoba S, Kang JG, Patino WD, Wragg A, Boehm M, Gavrilova O, Hurley PJ, Bunz F \& Hwang PM 2006 p53 regulates mitochondrial respiration. Science 312 1650-1653. (doi:10.1126/science. 1126863) 
Mayo LD \& Donner DB 2001 A phosphatidylinositol 3-kinase/Akt pathway promotes translocation of Mdm2 from the cytoplasm to the nucleus. PNAS 98 11598-11603. (doi:10.1073/pnas.181181198)

Menendez D, Shatz M \& Resnick MA 2013 Interactions between the tumor suppressor p53 and immune responses. Current Opinion in Oncology 25 85-92. (doi:10.1097/CCO.0b013e32835b6386)

Minamino T, Orimo M, Shimizu I, Kunieda T, Yokoyama M, Ito T, Nojima A, Nabetani A, Oike Y, Matsubara H, et al. 2009 A crucial role for adipose tissue p53 in the regulation of insulin resistance. Nature Medicine 15 1082-1087. (doi:10.1038/nm.2014)

Molchadsky A, Ezra O, Amendola PG, Krantz D, Kogan-Sakin I, Buganim Y, Rivlin N, Goldfinger N, Folgiero V, Falcioni R, et al. 2013 p53 is required for brown adipogenic differentiation and has a protective role against diet-induced obesity. Cell Death and Differentiation 20 774-783. (doi:10.1038/cdd.2013.9)

Morimoto Y, Bando YK, Shigeta T, Monji A \& Murohara T 2011 Atorvastatin prevents ischemic limb loss in type 2 diabetes: role of p53. Journal of Atherosclerosis and Thrombosis 18 200-208. (doi:10.5551/jat.6437)

Moyers JS, Bilan PJ, Reynet C \& Kahn CR 1996 Overexpression of Rad inhibits glucose uptake in cultured muscle and fat cells. Journal of Biological Chemistry 271 23111-23116. (doi:10.1074/jbc.271.38.23111)

Muris DM, Houben AJ, Schram MT \& Stehouwer CD 2012 Microvascular dysfunction is associated with a higher incidence of type 2 diabetes mellitus: a systematic review and meta-analysis. Arteriosclerosis, Thrombosis, and Vascular Biology 32 3082-3094. (doi:10.1161/ ATVBAHA.112.300291)

Nakatsuka A, Wada J, Hida K, Hida A, Eguchi J, Teshigawara S, Murakami K, Kanzaki M, Inoue K, Terami T, et al. 2012 RXR antagonism induces G0 /G1 cell cycle arrest and ameliorates obesity by up-regulating the p53-p21(Cip1) pathway in adipocytes. Journal of Pathology 226 784-795. (doi:10.1002/path.3001)

Nguyen PD, Tutela JP, Thanik VD, Knobel D, Allen RJ Jr, Chang CC, Levine JP, Warren SM \& Saadeh PB 2010 Improved diabetic wound healing through topical silencing of p53 is associated with augmented vasculogenic mediators. Wound Repair and Regeneration 18 553-559. (doi:10.1111/j.1524-475X.2010.00638.x)

Orimo M, Minamino T, Miyauchi H, Tateno K, Okada S, Moriya J \& Komuro I 2009 Protective role of SIRT1 in diabetic vascular dysfunction. Arteriosclerosis, Thrombosis, and Vascular Biology 29 889-894. (doi:10.1161/ATVBAHA.109.185694)

Palacino JJ, Sagi D, Goldberg MS, Krauss S, Motz C, Wacker M, Klose J \& Shen J 2004 Mitochondrial dysfunction and oxidative damage in parkin-deficient mice. Journal of Biological Chemistry 279 18614-18622. (doi:10.1074/jbc.M401135200)

Panasiuk A, Dzieciol J, Panasiuk B \& Prokopowicz D 2006 Expression of p53, Bax and Bcl-2 proteins in hepatocytes in non-alcoholic fatty liver disease. World Journal of Gastroenterology 12 6198-6202. (doi:10.3748/wjg.v12.i38.6198)

Pietsch EC, Sykes SM, McMahon SB \& Murphy ME 2008 The p53 family and programmed cell death. Oncogene 27 6507-6521. (doi:10.1038/ onc.2008.315)

Polonsky KS 2012 The past 200 years in diabetes. New England Journal of Medicine 367 1332-1340. (doi:10.1056/NEJMra1110560)

Porteiro B, Diaz-Ruiz A, Martinez G, Senra A, Vidal A, Serrano M, Gualillo O, Lopez M, Malagon MM, Dieguez C, et al. 2013 Ghrelin requires p53 to stimulate lipid storage in fat and liver. Endocrinology 154 3671-3679. (doi:10.1210/en.2013-1176)

Poyurovsky MV \& Prives C 2010 P53 and aging: a fresh look at an old paradigm. Aging 2 380-382. (doi:10.18632/aging.100179)

Puzio-Kuter AM 2011 The role of p53 in metabolic regulation. Genes Cancer 2 385-391. (doi:10.1177/1947601911409738)

Qi Z, He J, Zhang Y, Shao Y \& Ding S 2011 Exercise training attenuates oxidative stress and decreases p53 protein content in skeletal muscle of type 2 diabetic Goto-Kakizaki rats. Free Radical Biology \& Medicine 50 794-800. (doi:10.1016/j.freeradbiomed.2010.12.022)
Qu L, He B, Pan Y, Xu Y, Zhu C, Tang Z, Bao Q, Tian F \& Wang S 2011 Association between polymorphisms in RAPGEF1, TP53, NRF1 and type 2 diabetes in Chinese Han population. Diabetes Research and Clinical Practice 91 171-176. (doi:10.1016/ j.diabres.2010.11.019)

Reiling E, Lyssenko V, Boer JM, Imholz S, Verschuren WM, Isomaa B, Tuomi T, Groop L \& Dolle ME 2012 Codon 72 polymorphism (rs1042522) of TP53 is associated with changes in diastolic blood pressure over time. European Journal of Human Genetics 20 696-700. (doi:10.1038/ejhg.2011.240)

Reynet C \& Kahn CR 1993 Rad: a member of the Ras family overexpressed in muscle of type II diabetic humans. Science $\mathbf{2 6 2}$ 1441-1444. (doi:10.1126/science.8248782)

Rother K, Johne C, Spiesbach K, Haugwitz U, Tschop K, Wasner M, Klein-Hitpass L, Moroy T, Mossner J \& Engeland K 2004 Identification of Tcf-4 as a transcriptional target of p53 signalling. Oncogene 23 3376-3384. (doi:10.1038/sj.onc.1207464)

Ruiz-Lozano P, Hixon ML, Wagner MW, Flores AI, Ikawa S, Baldwin AS Jr, Chien KR \& Gualberto A 1999 p53 is a transcriptional activator of the muscle-specific phosphoglycerate mutase gene and contributes in vivo to the control of its cardiac expression. Cell Growth \& Differentiation 10 295-306.

Samarakoon R, Overstreet JM, Higgins SP \& Higgins PJ 2012 TGFbeta1 --> SMAD/p53/USF2 --> PAI-1 transcriptional axis in ureteral obstruction-induced renal fibrosis. Cell and Tissue Research $\mathbf{3 4 7}$ 117-128. (doi:10.1007/s00441-011-1181-y)

Samuel VT \& Shulman GI 2012 Mechanisms for insulin resistance: common threads and missing links. Cell 148 852-871. (doi:10.1016/ j.cell.2012.02.017)

Sano M, Minamino T, Toko H, Miyauchi H, Orimo M, Qin Y, Akazawa H, Tateno K, Kayama Y, Harada M, et al. 2007 p53-induced inhibition of Hif-1 causes cardiac dysfunction during pressure overload. Nature 446 444-448. (doi:10.1038/nature05602)

Schwartzenberg-Bar-Yoseph F, Armoni M \& Karnieli E 2004 The tumor suppressor p53 down-regulates glucose transporters GLUT1 and GLUT4 gene expression. Cancer Research 64 2627-2633. (doi:10.1158/0008-5472.CAN-03-0846)

Secchiero P, Toffoli B, Melloni E, Agnoletto C, Monasta L \& Zauli G 2013 The MDM2 inhibitor Nutlin-3 attenuates streptozotocininduced diabetes mellitus and increases serum level of IL-12p40. Acta Diabetologica 50 899-906. (doi:10.1007/s00592-013-0476-8)

Sen N, Satija YK \& Das S 2011 PGC-1alpha, a key modulator of p53, promotes cell survival upon metabolic stress. Molecular Cell $\mathbf{4 4}$ 621-634. (doi:10.1016/j.molcel.2011.08.044)

Shang X, Vasudevan SA, Yu Y, Ge N, Ludwig AD, Wesson CL, Wang K, Burlingame SM, Zhao YJ, Rao PH, et al. 2010 Dual-specificity phosphatase 26 is a novel p53 phosphatase and inhibits p53 tumor suppressor functions in human neuroblastoma. Oncogene 29 4938-4946. (doi:10.1038/onc.2010.244)

Shaw RJ \& Cantley LC 2006 Ras, PI(3)K and mTOR signalling controls tumour cell growth. Nature 441 424-430. (doi:10.1038/nature04869)

Shepherd PR \& Kahn BB 1999 Glucose transporters and insulin action-implications for insulin resistance and diabetes mellitus. New England Journal of Medicine 341 248-257. (doi:10.1056/NEJM199907223410406)

Shimizu I, Yoshida Y, Katsuno T, Tateno K, Okada S, Moriya J, Yokoyama M, Nojima A, Ito T, Zechner R, et al. 2012 p53-induced adipose tissue inflammation is critically involved in the development of insulin resistance in heart failure. Cell Metabolism 15 51-64. (doi:10.1016/j.cmet.2011.12.006)

Shimizu I, Yoshida Y, Moriya J, Nojima A, Uemura A, Kobayashi Y \& Minamino T 2013 Semaphorin3E-induced inflammation contributes to insulin resistance in dietary obesity. Cell Metabolism 18 491-504. (doi:10.1016/j.cmet.2013.09.001)

Speliotes EK, Willer CJ, Berndt SI, Monda KL, Thorleifsson G, Jackson AU, Lango Allen H, Lindgren CM, Luan J, Magi R, et al. 2010 Association analyses of 249,796 individuals reveal 18 new 
loci associated with body mass index. Nature Genetics 42 937-948. (doi:10.1038/ng.686)

Spitsina EV, Iakunina N, Chudakova DA, Nikitin AG, Svetlova GN, Soluianova TN, Strokov IA \& Nosikov VV 2007 [Association of polymorphous markers Pro72Arg and C(-594)CC OF TP53 gene with diabetic polyneuropathy in patients with type 1 diabetes mellitus living in Moscow]. Molekuliarnaia Biologiia 41 989-993.

Stavridi ES \& Halazonetis TD 2004 p53 and stress in the ER. Genes \& Development 18 241-244. (doi:10.1101/gad.1181704)

Szoke D, Molnar B, Solymosi N, Racz K, Gergics P, Blasko B, Vasarhelyi B, Vannay A, Mandy Y, Klausz G, et al. 2009 Polymorphisms of the ApoE, HSD3B1, IL-1beta and p53 genes are associated with the development of early uremic complications in diabetic patients: results of a DNA resequencing array study. International Journal of Molecular Medicine 23 217-227. (doi:10.3892/ijmm_00000120)

Takagi M, Tsuchida R, Oguchi K, Shigeta T, Nakada S, Shimizu K, Ohki M, Delia D, Chessa L, Taya Y, et al. 2004 Identification and characterization of polymorphic variations of the ataxia telangiectasia mutated (ATM) gene in childhood Hodgkin disease. Blood 103 283-290. (doi:10.1182/blood-2003-01-0094)

Tavana O, Puebla-Osorio N, Sang M \& Zhu C 2010 Absence of p53-dependent apoptosis combined with nonhomologous end-joining deficiency leads to a severe diabetic phenotype in mice. Diabetes 59 135-142. (doi:10.2337/db09-0792)

Tomita K, Teratani T, Suzuki T, Oshikawa T, Yokoyama H, Shimamura K, Nishiyama K, Mataki N, Irie R, Minamino T, et al. 2012 p53/p66Shcmediated signaling contributes to the progression of non-alcoholic steatohepatitis in humans and mice. Journal of Hepatology $\mathbf{5 7}$ 837-843. (doi:10.1016/j.jhep.2012.05.013)

Tornovsky-Babeay S, Dadon D, Ziv O, Tzipilevich E, Kadosh T, Schyr-Ben Haroush R, Hija A, Stolovich-Rain M, Furth-Lavi J, Granot Z, et al. 2014 Type 2 diabetes and congenital hyperinsulinism cause DNA double-strand breaks and p53 activity in beta cells. Cell Metabolism 19 109-121. (doi:10.1016/j.cmet.2013.11.007)

Vander Heiden MG, Cantley LC \& Thompson CB 2009 Understanding the Warburg effect: the metabolic requirements of cell proliferation. Science 324 1029-1033. (doi:10.1126/science.1160809)

Velasquez DA, Martinez G, Romero A, Vazquez MJ, Boit KD, Dopeso-Reyes IG, Lopez M, Vidal A, Nogueiras R \& Dieguez C 2011 The central Sirtuin 1/p53 pathway is essential for the orexigenic action of ghrelin. Diabetes 60 1177-1185. (doi:10.2337/db10-0802)

Voight BF, Scott LJ, Steinthorsdottir V, Morris AP, Dina C, Welch RP, Zeggini E, Huth C, Aulchenko YS, Thorleifsson G, et al. 2010 Twelve type 2 diabetes susceptibility loci identified through large-scale association analysis. Nature Genetics 42 579-589. (doi:10.1038/ng.609)

Vousden KH \& Prives C 2009 Blinded by the light: the growing complexity of p53. Cell 137 413-431. (doi:10.1016/j.cell.2009.04.037)

Vousden KH \& Ryan KM 2009 p53 and metabolism. Nature Reviews. Cancer 9 691-700. (doi:10.1038/nrc2715)

Wang Y, Rimm EB, Stampfer MJ, Willett WC \& Hu FB 2005 Comparison of abdominal adiposity and overall obesity in predicting risk of type 2 diabetes among men. American Journal of Clinical Nutrition 81 555-563.

Wang SJ, Yu G, Jiang L, Li T, Lin Q, Tang Y \& Gu W 2013 p53-Dependent regulation of metabolic function through transcriptional activation of pantothenate kinase-1 gene. Cell Cycle 12 753-761. (doi:10.4161/ cc.23597)

Webster NJ, Resnik JL, Reichart DB, Strauss B, Haas M \& Seely BL 1996 Repression of the insulin receptor promoter by the tumor suppressor gene product p53: a possible mechanism for receptor overexpression in breast cancer. Cancer Research 56 2781-2788.
Whibley C, Pharoah PD \& Hollstein M 2009 p53 polymorphisms: cancer implications. Nature Reviews. Cancer 9 95-107. (doi:10.1038/nrc2584)

Williams KH, Shackel NA, Gorrell MD, McLennan SV \& Twigg SM 2013 Diabetes and nonalcoholic Fatty liver disease: a pathogenic duo. Endocrine Reviews 34 84-129. (doi:10.1210/er.2012-1009)

Wrede CE, Dickson LM, Lingohr MK, Briaud I \& Rhodes CJ 2002 Protein kinase B/Akt prevents fatty acid-induced apoptosis in pancreatic beta-cells (INS-1). Journal of Biological Chemistry $27749676-49684$. (doi:10.1074/jbc.M208756200)

Yahagi N, Shimano H, Matsuzaka T, Najima Y, Sekiya M, Nakagawa Y, Ide T, Tomita S, Okazaki H, Tamura Y, et al. 2003 p53 Activation in adipocytes of obese mice. Journal of Biological Chemistry $\mathbf{2 7 8}$ 25395-25400. (doi:10.1074/jbc.M302364200)

Yahagi N, Shimano H, Matsuzaka T, Sekiya M, Najima Y, Okazaki S, Okazaki H, Tamura Y, Iizuka Y, Inoue N, et al. 2004 p53 involvement in the pathogenesis of fatty liver disease. Journal of Biological Chemistry 279 20571-20575. (doi:10.1074/jbc. M400884200)

Yamauchi T, Waki H, Kamon J, Murakami K, Motojima K, Komeda K, Miki H, Kubota N, Terauchi Y, Tsuchida A, et al. 2001 Inhibition of RXR and PPARgamma ameliorates diet-induced obesity and type 2 diabetes. Journal of Clinical Investigation 108 1001-1013. (doi:10.1172/ JCI12864)

Yokoyama M, Okada S, Nakagomi A, Moriya J, Shimizu I, Nojima A, Yoshida Y, Ichimiya H, Kamimura N, Kobayashi Y, et al. 2014 Inhibition of endothelial p53 improves metabolic abnormalities related to dietary obesity. Cell Reports 7 1691-1703. (doi:10.1016/j.celrep.2014.04.046)

Yuan H, Zhang X, Huang X, Lu Y, Tang W, Man Y, Wang S, Xi J \& Li J 2010 NADPH oxidase 2-derived reactive oxygen species mediate FFAs-induced dysfunction and apoptosis of beta-cells via JNK, p38 MAPK and p53 pathways. PLoS ONE 5 e15726. (doi:10.1371/journal. pone.0015726)

Zhang C, Lin M, Wu R, Wang X, Yang B, Levine AJ, Hu W \& Feng Z 2011 Parkin, a p53 target gene, mediates the role of p53 in glucose metabolism and the Warburg effect. PNAS 108 16259-16264. (doi:10.1073/pnas.1113884108)

Zhang C, Liu J, Liang Y, Wu R, Zhao Y, Hong X, Lin M, Yu H, Liu L, Levine AJ, et al. 2013 Tumour-associated mutant p53 drives the Warburg effect. Nature Communications 4 2935. (doi:10.1038/ncomms2341)

Zhang C, Liu J, Wu R, Liang Y, Lin M, Liu J, Chan CS, Hu W \& Feng Z 2014 Tumor suppressor p53 negatively regulates glycolysis stimulated by hypoxia through its target RRAD. Oncotarget 5 5535-5546. (doi:10.18632/oncotarget.2137)

Zhao Y, Tan Y, Dai J, Li B, Guo L, Cui J, Wang G, Shi X, Zhang X, Mellen N, et al. 2011 Exacerbation of diabetes-induced testicular apoptosis by zinc deficiency is most likely associated with oxidative stress, p38 MAPK activation, and p53 activation in mice. Toxicology Letters 200 100-106. (doi:10.1016/j.toxlet.2010.11.001)

Zhou BP, Liao Y, Xia W, Zou Y, Spohn B \& Hung MC 2001 HER-2/neu induces p53 ubiquitination via Akt-mediated MDM2 phosphorylation. Nature Cell Biology 3 973-982. (doi:10.1038/ncb1101-973)

Zhou Y, Zhang E, Berggreen C, Jing X, Osmark P, Lang S, Cilio CM, Goransson O, Groop L, Renstrom E, et al. 2012 Survival of pancreatic beta cells is partly controlled by a TCF7L2-p53-p53INP1-dependent pathway. Human Molecular Genetics 21 196-207. (doi:10.1093/hmg/ ddr454)

Zwetsloot KA, Childs TE, Gilpin LT \& Booth FW 2013 Non-passaged muscle precursor cells from 32-month old rat skeletal muscle have delayed proliferation and differentiation. Cell Proliferation 46 45-57. (doi:10.1111/cpr.12007)

Received in final form 31 August 2016

Accepted 8 September 2016

Accepted Preprint published online 9 September 2016 http://joe.endocrinology-journals.org

DOI: 10.1530/JOE-16-0324
๑ 2016 Society for Endocrinology Printed in Great Britain 